\title{
High (but Not Low) Urinary lodine Excretion Is Predicted by lodine Excretion Levels from Five Years Ago
}

\author{
Till Ittermann ${ }^{\mathrm{a}, \mathrm{b}} \quad$ Anke Nautsch ${ }^{\mathrm{a}} \quad$ Carsten Oliver Schmidt ${ }^{\mathrm{a}} \quad$ Axel Kramer $^{\mathrm{c}}$ \\ Harald Below $^{c}$ Thomas Remer ${ }^{d}$ Roland Gärtner ${ }^{\mathrm{e}}$ Henri Wallaschofski ${ }^{\mathrm{b}}$ \\ Henry Völzkea
}

Institutes of a Community Medicine, ${ }^{\mathrm{b}}$ Clinical Chemistry and Laboratory Medicine and ${ }^{\mathrm{c}} \mathrm{Hyg}$ iene and Environmental Medicine, University of Greifswald, Greifswald, dDepartment of Nutrition and Health, Research Institute of Child Nutrition, Dortmund, and ${ }^{\mathrm{e}}$ Medizinische Klinik Innenstadt, University of Munich, Munich, Germany

\section{Key Words}

Urinary iodine excretion · lodine status · Prediction

\begin{abstract}
Background: It has not been investigated whether there are associations between urinary iodine (UI) excretion measurements some years apart, nor whether such an association remains after adjustment for nutritional habits. The aim of the present study was to investigate the relation between iodine-creatinine ratio (ICR) at two measuring points 5 years apart. Methods: Data from 2,659 individuals from the Study of Health in Pomerania were analyzed. Analysis of covariance and Poisson regressions were used to associate baseline with follow-up ICR. Results: Baseline ICR was associated with follow-up ICR. Particularly, baseline ICR $>300 \mu \mathrm{g} / \mathrm{g}$ was related to an ICR $>300 \mu \mathrm{g} / \mathrm{g}$ at follow-up (relative risk, RR: 2.20; $\mathrm{p}<$ 0.001). The association was stronger in males (RR: 2.64; $p<$ 0.001 ) than in females (RR: 1.64; $p=0.007$ ). In contrast, baseline ICR $<100 \mu \mathrm{g} / \mathrm{g}$ was only associated with an ICR $<100$ $\mu \mathrm{g} / \mathrm{g}$ at follow-up in males when considering unadjusted ICR. Conclusions: We detected only a weak correlation with
\end{abstract}

\section{KARGER}

Fax +41613061234 E-Mail karger@karger.ch www.karger.com

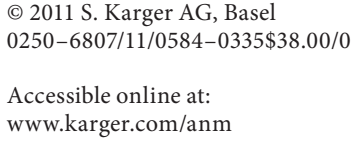

respect to low ICR. Studies assessing iodine status in a population should take into account that an individual with a low UI excretion in one measurement is not necessarily permanently iodine deficient. On the other hand, current high ICR could have been predicted by high ICR 5 years ago.

Copyright ๑ 2011 S. Karger AG, Basel

\section{Introduction}

Urinary iodine (UI) excretion is used to determine the state of iodine supply in populations. Large intra-individual variations in UI excretion concentrations arise mainly from variable iodine ingestion. Most ingested iodine is excreted on the day of ingestion [1], with a peak at 4-5 h after a main meal [2]. Some sources of nutrition, such as sea fish [3] and milk [4, 5], include a large amount of iodine. So far, few studies have investigated intra-individual variations in UI excretion [1, 2, 6-9], with the result

T.I. and A.N. contributed equally to the paper.
Till Ittermann, Dipl-Stat.

Institute of Community Medicine

Ernst Moritz Arndt University

Walther Rathenau Str. 48, DE-17487 Greifswald (Germany)

Tel.+493834867539, E-Mail till.ittermann@uni-greifswald.de 
that a single non-fasting spot urine sample gives only rough information on a subject's iodine status, with even several samples being insufficient. All of these studies [ 1 , 2, 6-9] were conducted with less than 200 participants and focused on day-to-day variations in iodine concentrations.

According to the World Health Organization, iodine deficiency is defined as a UI excretion below $100 \mu \mathrm{g} / \mathrm{l}[10]$. To assess the iodine status in populations, this criteria is widely used. However, it is difficult to categorize an individual as permanently iodine deficient based on only one UI measurement since the intra-individual variation in UI excretion levels is large. Consequently, the number of permanent iodine deficient individuals might be overestimated in these studies.

Thus, the aim of the present study was to investigate the relation between unadjusted as well as adjusted iodine-creatinine ratio (ICR) at two measuring points 5 years apart in a large population-based study. Nutritional habits were considered in all calculations.

\section{Design and Methods}

Study Subjects

The Study of Health in Pomerania (SHIP) is a populationbased cohort study in West Pomerania, a region in the northeast of Germany containing the three cities Greifswald, Stralsund and Anklam, and 29 surrounding communities [11]. Like most parts of Germany, West Pomerania is a region of former iodine deficiency [12]. During the last 15 years, iodine supply has been normalized due to an effective iodine fortification program.

The total population comprised 212,157 inhabitants. For baseline examinations, a sample from the population aged 20-79 years was drawn from population registries, in which every German resident is listed. The net sample (without migrated or deceased persons) comprised 6,267 eligible subjects. SHIP finally included 4,310 participants (2,117 men and 2,193 women) corresponding to a response of $68.8 \%$ [11]. Baseline examinations were conducted between 1997 and 2001. Between 2002 and 2006, all participants were re-invited to take part in a 5-year examination followup, of which 3,300 subjects took part (1,589 men and 1,711 women; $83.5 \%$ of all eligible subjects). The median follow-up time was 5.0 years (minimum, 4.4 years; maximum, 8.6 years; $17,314.5$ personyears). All participants gave informed written consent. The study followed the recommendations of the Declaration of Helsinki and was approved by the Ethics Committee of the University of Greifswald.

Of the 3,300 individuals who participated at baseline and follow-up, 162 subjects ( 90 women) had missing data in one of the considered variables, a further 459 subjects ( 350 women) received thyroid medication, and 20 subjects ( 6 women) had renal failure. These 641 individuals (446 women) were excluded from further analysis, which resulted in a study population of 2,659 participants (1,265 women).

\section{Assessments}

Sociodemographic characteristics and medical histories on thyroid disorders were assessed by computer-aided personal interviews. Education was categorized into two levels (low, $\leq 10$ years; high, $>10$ years). Ingestion of fish, milk and eggs were selected from a food-frequency questionnaire [13]. For each nutrient, participants were defined as regular consumers if the nutrient was ingested at least once during the last week. Renal failure was defined by a glomerular filtration rate $<30 \mathrm{ml} / \mathrm{min} / 1.73 \mathrm{~m}^{2}$, which was estimated by the simplified Modification of Diet in Renal Disease formula eGFR $=186 \times$ serum $_{\text {creatinine }}{ }^{-1.154} \times$ age $^{-0.203}[\times 0.742$ if female]. Weight was measured to the nearest $0.1 \mathrm{~kg}$ in light clothing and without shoes using standard digital scales (Soehnle-Waagen GmbH, Nassau, Germany). Thyroid ultrasonography was performed in both examinations using an Ultrasound VST-Gateway with a $5-\mathrm{MHz}$ linear array transducer (Diasonics, Santa Clara, Calif., USA). Thyroid volume was calculated as length $\times$ width $\times$ depth $\times 0.479(\mathrm{ml})$ for each lobe [14]. Goiter was defined as a thyroid volume of $>18 \mathrm{ml}$ in women and $>5 \mathrm{ml}$ in men [15].

Spot urine samples were collected between 07.00 a.m. and 04.00 p.m. and analyzed for iodine concentration by a photometric procedure (Photometer ECOM 6122; Eppendorf, Hamburg, Germany) with Sandell and Kolthoff reaction [16]. Urinary creatinine was analyzed on the basis of the Jaffé reaction [17], and ICR was calculated. During the course of the study, the inter-assay coefficient of variation for iodine was $4.18 \%$. Additionally, we computed age- and sex-adjusted ICR using the following formula: iodine $(\mu \mathrm{g} / \mathrm{l}) /[\mathrm{cre}-$ atinine (g/l)/expected creatinine excretion (g/day)]. Expected creatinine 24-hour excretion values were calculated according to a Belgian population-based study [18, 19]. The expected 24-hour creatinine excretion for men declined from $1.74 \mathrm{~g}$ (25-49 years) through $1.63 \mathrm{~g}(50-59$ years) and $1.47 \mathrm{~g}$ (60-69 years) to $1.39 \mathrm{~g}(\geq 70$ years). For women, values were $1.23 \mathrm{~g}$ (25-49 years), $1.15 \mathrm{~g}$ (50-59 years), $1.07 \mathrm{~g}$ (60-69 years) and $1.00 \mathrm{~g}$ ( $\geq 70$ years). Participants were segmented into three groups according to ICR at baseline (cutoffs: 100 and $300 \mu \mathrm{g} / \mathrm{g}$ ). Spot urine samples were classified into four categories based on the time of collecting: before $12 \mathrm{a} . \mathrm{m}$. at baseline and follow-up, after 12.00 a.m. at baseline and follow-up, before $12.00 \mathrm{a} . \mathrm{m}$. at baseline and after $12.00 \mathrm{a} . \mathrm{m}$. at follow-up, and after $12.00 \mathrm{a} . \mathrm{m}$. at baseline and before $12.00 \mathrm{a} . \mathrm{m}$. at follow-up.

\section{Statistical Analyses}

Data on quantitative characteristics are expressed as medians and interquartile ranges (IQR). Data on qualitative characteristics are expressed as percent values or absolute numbers as indicated. Comparisons between groups were made using Chisquared test (qualitative data) or Wilcoxon test (quantitative data). Wilcoxon's signed-rank test was used for paired data. ICR concentrations at baseline were associated with ICR concentrations at follow-up by linear and Poisson regression models [20]. All models were adjusted for age, sex, weight, time of urine sampling, time between baseline and follow-up, and ingestion of fish, eggs and milk. The same adjustments were used for analyzing the association of baseline ICR with incident goiter. For this analysis, a further 19 participants with history of thyroid surgery between baseline and follow-up were excluded. A value of $\mathrm{p}<0.05$ was considered statistically significant. To assess the sensitivity of our results to nonresponse and dropout, we applied statistical weights. The aim of this approach was to give more 


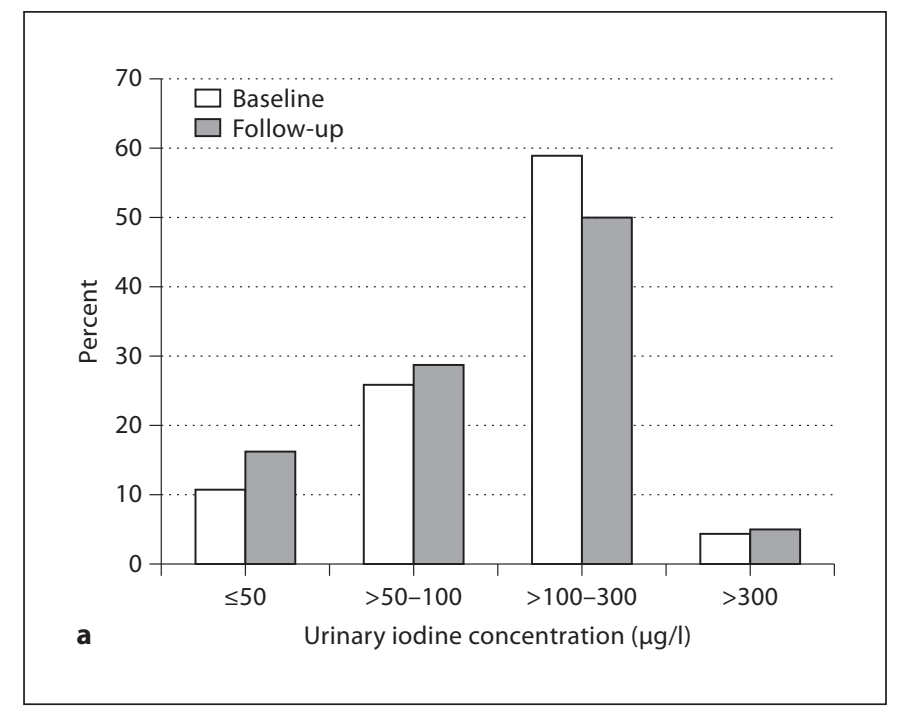

Fig. 1. UI concentrations (a) and ICR (b) at baseline and follow-up.

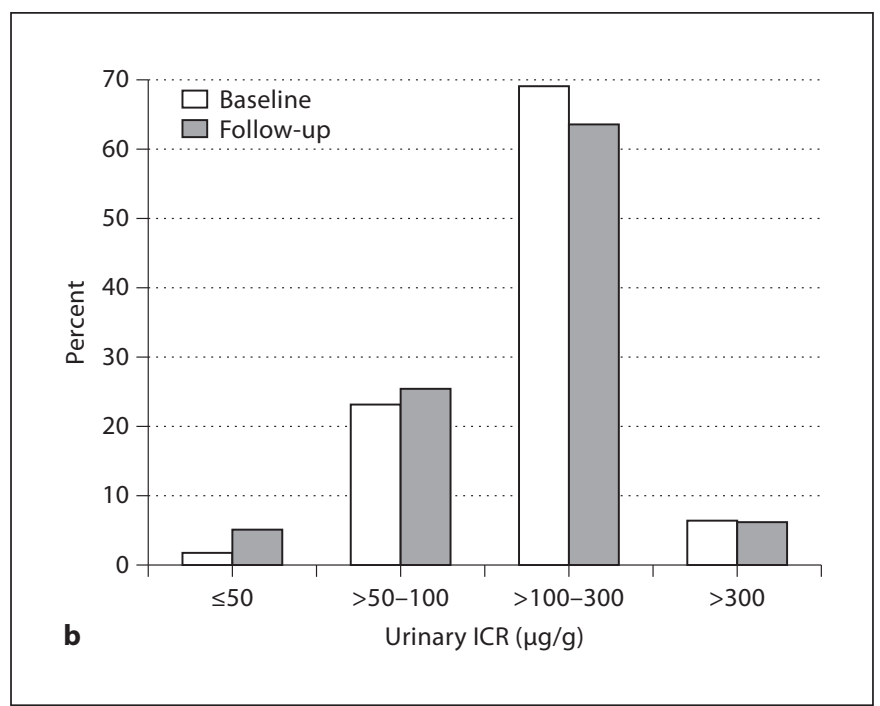

weight to subjects whose propensity to drop out of the study was high. The weights accounted for nonresponse to baseline (SHIP0 ) and for dropout to follow-up (SHIP-1) based on sociodemographic and health-related variables. Robust standard errors were computed for all weighted analyses. All statistical analyses were performed with SAS 9.1 (SAS Institute, Inc., Cary, N.C., USA). This paper was written in accordance with the STROBE statement, giving guidelines for reporting observational studies [21].

\section{Results}

UI concentrations (fig. 1a) and ICR (fig. 1b) at baseline and follow-up are presented. Median UI concentrations decreased from $125 \mu \mathrm{g} / \mathrm{l}$ (IQR: 76.4-180.0 $\mu \mathrm{g} / \mathrm{l}$ ) at baseline to $111 \mu \mathrm{g} / \mathrm{l}$ (IQR: 64.3-173.0 $\mu \mathrm{g} / \mathrm{l})$ at follow-up ( $<<$ 0.001), and median ICR decreased from $134.2 \mu \mathrm{g} / \mathrm{g}$ (IQR: 100.3-179.6 $\mu \mathrm{g} / \mathrm{g}$ ) to $130.4 \mu \mathrm{g} / \mathrm{g}$ (IQR: 92.2-179.0 $\mu \mathrm{g} / \mathrm{g}$ ) $(\mathrm{p}=0.002)$. Consequently, there were fewer participants with a UI concentration of $<100 \mu \mathrm{g} / \mathrm{l}$ or an ICR of $<100$ $\mu \mathrm{g} / \mathrm{g}$ at baseline than at follow-up (table 1), but no differences between baseline and follow-up for a UI concentration $>300 \mu \mathrm{g} / \mathrm{l}$ or an ICR $>300 \mu \mathrm{g} / \mathrm{g}$. Of those participants who had an ICR $<100 \mu \mathrm{g} / \mathrm{g}$ at baseline, $42.0 \%$ maintained $<100 \mu \mathrm{g} / \mathrm{g}$ at follow-up. Of those participants who had an ICR $>300 \mu \mathrm{g} / \mathrm{g}$ at baseline, $19.0 \%$ maintained $>300 \mu \mathrm{g} / \mathrm{g}$ at follow-up. Table 1 shows the characteristics of the study population stratified by sex. UI concentrations were higher in males than in females, whereas ICR was lower in males than in females, and adjusted ICR was comparable between the sexes.

Multivariable Poisson regression analyses revealed a significant association between an ICR $\leq 100 \mu \mathrm{g} / \mathrm{g}$ at baseline and an ICR $\leq 100 \mu \mathrm{g} / \mathrm{g}$ at follow-up in the whole population (table 2). This association was only present in males, but not in females. An ICR $>300 \mu \mathrm{g} / \mathrm{g}$ at baseline was significantly associated with an ICR $>300 \mu \mathrm{g} / \mathrm{g}$ at follow-up. This association was present in both sexes.

Adjusted ICR $\leq 100 \mu \mathrm{g} / \mathrm{g}$ was not associated with an adjusted $\mathrm{ICR} \leq 100 \mu \mathrm{g} / \mathrm{g}$ at follow-up (table 3 ). Also stratification by sex showed no significant effects. Adjusted ICR $>300 \mu \mathrm{g} / \mathrm{g}$ at baseline was significantly associated with an ICR $>300 \mu \mathrm{g} / \mathrm{g}$ at follow-up. This association was present in both sexes, and was stronger in males than in females.

There were no significant associations between baseline unadjusted ICR and incident goiter in multivariable analysis for both sexes. In males, baseline-adjusted ICR $>300 \mu \mathrm{g} /$ day was significantly associated with incident goiter (RR: 1.53; 95\% CI: 1.10-2.13; p value $=0.011$ )

\section{Discussion}

In the present study, we investigated the interdependency of two UI measurements 5 years apart. We detected a correlation between these measurements. In particular, the risk of having a high UI excretion $>300 \mu \mathrm{g} / \mathrm{g}$ at 
Table 1. Characteristics of the study population

\begin{tabular}{|c|c|c|}
\hline & $\begin{array}{l}\text { Men } \\
(\mathrm{n}=1,394)\end{array}$ & $\begin{array}{l}\text { Women } \\
(\mathrm{n}=1,265)\end{array}$ \\
\hline \multicolumn{3}{|l|}{ Baseline } \\
\hline Iodine, $\mu \mathrm{g} / \mathrm{l}$ & $137.0(93.3-187.0)$ & $109.0(63.2-170.0)$ \\
\hline ICR, $\mu \mathrm{g} / \mathrm{g}$ & $120.1(91.6-158.5)$ & $154.0(114.2-202.6)$ \\
\hline Adjusted ICR, $\mu \mathrm{g} /$ day & $192.8(149.0-251.9)$ & $179.6(134.7-235.9)$ \\
\hline $\mathrm{ICR}<100 \mu \mathrm{g} / \mathrm{g}$ & $448(32.1)$ & $210(16.6)$ \\
\hline ICR $>300 \mu \mathrm{g} / \mathrm{g}$ & $63(4.5)$ & $106(8.4)$ \\
\hline Adjusted ICR $<100 \mu \mathrm{g} /$ day & $77(5.5)$ & $113(8.9)$ \\
\hline Adjusted ICR $>300 \mu \mathrm{g} /$ day & $203(14.5)$ & $160(12.7)$ \\
\hline Age, years & $50.0(37.0-62.0)$ & $46.0(34.0-58.0)$ \\
\hline Weight, kg & $84.2(76.0-93.4)$ & $68.1(60.1-78.6)$ \\
\hline Higher education $>10$ years & $265(19.0)$ & $226(17.9)$ \\
\hline Ingestion of eggs (at least once a week) & $1,087(78.0)$ & $945(74.7)$ \\
\hline Ingestion of fish (at least once a week) & $627(45.0)$ & $530(41.9)$ \\
\hline Ingestion of milk (at least once a week) & $637(45.7)$ & $627(49.6)$ \\
\hline Goiter & $416(33.0)$ & $530(38.3)$ \\
\hline \multicolumn{3}{|l|}{ Follow-up } \\
\hline Iodine, $\mu \mathrm{g} / \mathrm{l}$ & $124.0(78.2-184.0)$ & $93.2(53.3-58.0)$ \\
\hline ICR, $\mu \mathrm{g} / \mathrm{g}$ & $113.9(82.8-155.1)$ & $149.4(107.8-205.1)$ \\
\hline Adjusted ICR, $\mu \mathrm{g} /$ day & $181.5(133.8-244.3)$ & $170.3(124.9-231.2)$ \\
\hline ICR $<100 \mu \mathrm{g} / \mathrm{g}$ & $548(39.3)$ & $259(20.5)$ \\
\hline ICR $>300 \mu \mathrm{g} / \mathrm{g}$ & $52(3.7)$ & $112(8.9)$ \\
\hline Adjusted ICR $<100 \mu \mathrm{g} /$ day & $176(12.6)$ & $175(13.8)$ \\
\hline Adjusted ICR $>300 \mu \mathrm{g} /$ day & $198(14.2)$ & $161(12.7)$ \\
\hline Goiter & $493(39.0)$ & $585(42.0)$ \\
\hline
\end{tabular}

Data are given as $\mathrm{n}(\%)$ or medians (IQR).

follow-up was five times higher for males with a high UI excretion $>300 \mu \mathrm{g} / \mathrm{g}$ at baseline compared to males with a UI excretion in the interval of $100-300 \mu \mathrm{g} / \mathrm{g}$ at baseline. In women, these associations were less strong, but the risk of having a high UI excretion $>300 \mu \mathrm{g} / \mathrm{g}$ at follow-up was still two times higher for women with a high UI excretion $>300 \mu \mathrm{g} / \mathrm{g}$ at baseline compared to females with a UI excretion in the interval of $100-300 \mu \mathrm{g} / \mathrm{g}$ at baseline. A correlation between UI excretion $\leq 100 \mu \mathrm{g} / \mathrm{g}$ between baseline and follow-up was detected only for unadjusted but not for adjusted ICR.

UI excretion is commonly used as a marker of iodine supply status in population studies [10]. With respect to low ICR $(<100 \mu \mathrm{g} / \mathrm{g})$, baseline ICR was only correlated with follow-up ICR in males when using unadjusted ICR. No correlation was detected for adjusted ICR. Our results suggest that participants who had a UI excretion of $<100$ $\mu \mathrm{g} / \mathrm{g}$ at baseline do not necessarily remain iodine deficient. Only a proportion of $42 \%$ of all participants had a low UI excretion at both measurements. This strongly indicates that cross-sectional studies to determine the iodine status in a population overestimate the proportion of iodine-deficient subjects.

In participants with a high ICR $(>300 \mu \mathrm{g} / \mathrm{g})$, the predictivity of ICR was better in males than in females. Besides nutritional factors, which might possibly explain these findings, several hypotheses might be generated from this finding. The UI excretion depends on the nutritional iodine intake, the iodine uptake into the thyroid gland and the perfusion of the kidney [22]. Individual setup of renal reabsorption may determine a loss of iodine $[23,24]$ and might be inhibited, e.g. by chronic renal insufficiency [25]. Also genetic variants may influence iodine metabolism and excretion [26]. Particularly, it has been previously reported that renal iodine re-uptake might be influenced by the renal sodium iodide symporter [27], which also transfers iodine into the thyroid cells. Inhibition of this mechanism might lead, hypothetically, 
Table 2. Association of categorized ICR at baseline with ICR at follow-up

\begin{tabular}{|c|c|c|c|}
\hline & $\begin{array}{l}\text { Model 1: analysis of covariance } \\
\text { adjusted ICR (continuous) } \\
\text { (follow-up) } \\
\beta\end{array}$ & $\begin{array}{l}\text { Model 2: Poisson regression } \\
\text { ICR }>100 \mu \mathrm{g} / \mathrm{g} \text { vs. ICR } \leq 100 \mu \mathrm{g} / \mathrm{g} \\
\text { (follow-up) } \\
\text { RR }\end{array}$ & $\begin{array}{l}\text { Model 3: Poisson regression } \\
\text { ICR }>300 \mu \mathrm{g} / \mathrm{g} \text { vs. ICR } \leq 300 \mu \mathrm{g} / \mathrm{g} \\
\text { (follow-up) } \\
\text { RR }\end{array}$ \\
\hline \\
\hline \multicolumn{4}{|l|}{ ICR (baseline) } \\
\hline $\begin{array}{l}0-100 \mu \mathrm{g} / \mathrm{g} \\
>100-300 \mu \mathrm{g} / \mathrm{g}\end{array}$ & $\begin{array}{l}-15.67(-38.58 \text { to } 7.24) ; \mathrm{p}=0.180 \\
\text { reference }\end{array}$ & $\begin{array}{l}0.87(0.82 \text { to } 0.94) ; \mathrm{p}<0.001 \\
\text { reference }\end{array}$ & $\begin{array}{l}0.82(0.52 \text { to } 1.29) ; \mathrm{p}=0.389 \\
\text { reference }\end{array}$ \\
\hline$>300 \mu \mathrm{g} / \mathrm{g}$ & 74.97 (35.32 to 114.62$) ; \mathrm{p}<0.001$ & $1.06(0.98$ to 1.15$) ; \mathrm{p}=0.130$ & $2.61(1.79$ to 3.82$) ; \mathrm{p}<0.001$ \\
\hline \multicolumn{4}{|l|}{ Men } \\
\hline \multicolumn{4}{|l|}{ ICR (baseline) } \\
\hline $\begin{array}{c}0-100 \mu \mathrm{g} / \mathrm{g} \\
>100-300 \mu \mathrm{g} / \mathrm{g}\end{array}$ & $\begin{array}{l}-25.74(-51.86 \text { to } 0.39) ; \mathrm{p}=0.053 \\
\text { reference }\end{array}$ & $\begin{array}{l}0.79(0.71 \text { to } 0.87) ; \mathrm{p}<0.001 \\
\text { reference }\end{array}$ & $\begin{array}{l}0.27(0.10 \text { to } 0.75) ; \mathrm{p}<0.001 \\
\text { reference }\end{array}$ \\
\hline$>300 \mu \mathrm{g} / \mathrm{g}$ & 152.62 (95.81 to 209.44$) ; \mathrm{p}<0.001$ & 1.08 (0.93 to 1.27$) ; \mathrm{p}=0.286$ & $4.66(2.51$ to 8.64$) ; \mathrm{p}<0.001$ \\
\hline \multicolumn{4}{|l|}{ Women } \\
\hline \multicolumn{4}{|l|}{ ICR (baseline) } \\
\hline $\begin{array}{c}0-100 \mu \mathrm{g} / \mathrm{g} \\
>100-300 \mu \mathrm{g} / \mathrm{g}\end{array}$ & $\begin{array}{l}22.88(-19.09 \text { to } 64.86) ; \mathrm{p}=0.285 \\
\text { reference }\end{array}$ & $\begin{array}{l}1.01(0.94 \text { to } 1.10) ; \mathrm{p}=0.738 \\
\text { reference }\end{array}$ & $\begin{array}{l}1.39(0.87 \text { to } 2.22) ; \mathrm{p}=0.174 \\
\text { reference }\end{array}$ \\
\hline$>300 \mu \mathrm{g} / \mathrm{g}$ & $23.72(-32.43$ to 79.89$) ; \mathrm{p}=0.407$ & $1.06(0.98$ to 1.15$) ; \mathrm{p}=0.168$ & $2.07(1.30$ to 3.28$) ; \mathrm{p}=0.002$ \\
\hline
\end{tabular}

Table 3. Association of categorized adjusted ICR at baseline with ICR at follow-up

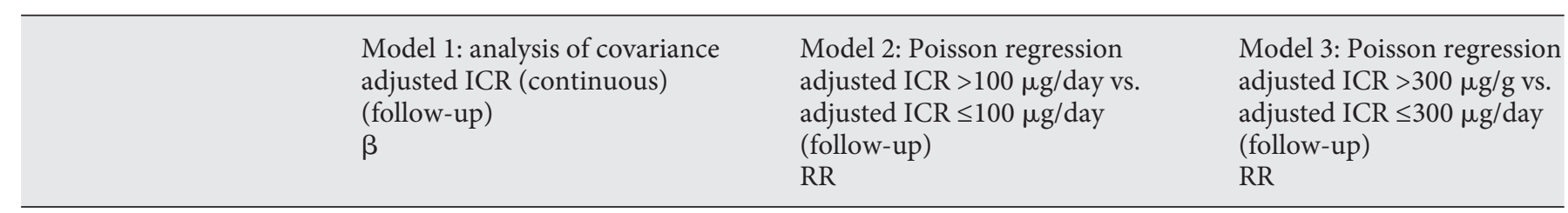

All

Adjusted ICR (baseline)

$0-100 \mu \mathrm{g} /$ day

$>100-300 \mu \mathrm{g} / \mathrm{day}$

$>300 \mu \mathrm{g} /$ day
-25.64 ( -74.16 to 22.89$) ; \mathrm{p}=0.300$ reference

78.77 (42.45 to 115.08 ); $\mathrm{p}<0.001$
0.97 ( 0.91 to 1.03 ); $\mathrm{p}=0.348$

reference

1.03 (0.99 to 1.07 ); $\mathrm{p}=0.189$
$1.02(0.67$ to 1.55$) ; \mathrm{p}=0.926$ reference

2.20 (1.78 to 2.71$) ; \mathrm{p}<0.001$

Men

Adjusted ICR (baseline)

$0-100 \mu \mathrm{g} /$ day

$>100-300 \mu \mathrm{g} /$ day $>300 \mu \mathrm{g} / \mathrm{day}$

$\begin{array}{ll}-43.93(-122.45 \text { to } 34.59) ; \mathrm{p}=0.273 & \begin{array}{l}0.94(0.85 \text { to } 1.05) ; \mathrm{p}=0.297 \\ \text { reference }\end{array} \\ 111.36(60.98 \text { to } 161.74) ; \mathrm{p}<0.001 & 1.03(0.98 \text { to } 1.08) ; \mathrm{p}=0.292\end{array}$

reference

1.03 (0.98 to 1.08 ); $\mathrm{p}=0.292$
$0.88(0.44$ to 1.75$) ; \mathrm{p}=0.712$ reference

2.64 (2.02 to 3.44); $\mathrm{p}<0.001$

\section{Women}

Adjusted ICR (baseline)

$0-100 \mu \mathrm{g} /$ day

$>100-300 \mu \mathrm{g} / \mathrm{day}$ $>300 \mu \mathrm{g} /$ day

\author{
$-13.08(-74.05$ to 47.89$) ; \mathrm{p}=0.674$ \\ reference \\ 37.00 ( -15.75 to 89.76$) ; \mathrm{p}=0.169$
}

0.99 (0.91 to 1.07$) ; \mathrm{p}=0.808$

reference

1.03 ( 0.96 to 1.09 ); $\mathrm{p}=0.434$
1.09 (0.65 to 1.82$) ; \mathrm{p}=0.757$ reference

1.64 (1.15 to 2.36$) ; \mathrm{p}=0.007$

Parentheses contain 95\% CI. All models were adjusted for age, weight, sex, education, ingestion of fish, milk and eggs, time between baseline and follow-up, and time of urine sampling. 
to a higher UI excretion and consequently to a higher risk of goiter. In our analysis, we detected a statistically significant association between high adjusted ICR $(>300$ $\mu \mathrm{g} /$ day) at baseline and incident goiter in males. These results at least partly support the hypothetical UI loss in affected individuals.

Our study indicates that there is a considerable proportion of individuals with a hypothetical iodine loss. In SHIP, $4.5 \%$ of men and $2.5 \%$ of women had an adjusted ICR $>300 \mu \mathrm{g} /$ day at both baseline and follow-up. Should further research demonstrate that high UI concentrations are present in a considerable proportion of these subjects due to inadequate iodine conservation rather than due to high iodine intake, these subjects should consequently be excluded from studies assessing the iodine status of populations. Otherwise, such studies would overestimate iodine status and the proportion of subjects with over-supply.

In general, ICR predictivity was stronger in males than in females. Potentially larger variations in nutritional habits in females and genetic as well as metabolic differences might be responsible for this phenomenon. This question cannot be answered by the present study. A longitudinal study with dietary records and genetic characterization is needed to clarify this point.

In contrast to some studies $[4,7,9]$, but in agreement with others $[1,19]$, we defined UI by ICR. A couple of studies $[8,28]$ advised against the use of ICR since it may underestimate UI concentrations compared to 24-hour urine and overestimate iodine concentrations in women compared to men. This problem was tackled using sexand age-adjusted ICR, which was reported to be superior over UI concentrations and unadjusted ICR [19]. In the present analysis, calculations with adjusted and unadjusted ICR revealed similar results. For both definitions, high UI excretion at baseline was significantly associated with UI excretion at follow-up. The relative risk was lower when using adjusted ICR, but confidence limits were smaller compared to analysis with unadjusted ICR.

In SHIP, urine samples were taken in a non-fasting state between $07.00 \mathrm{a} . \mathrm{m}$. and $04.00 \mathrm{p} . \mathrm{m}$. The existence of a circadian rhythm in UI concentrations is currently under debate. Two studies detected a circadian rhythm in UI concentrations $[2,29]$, whereas two others did not $[1$, 28]. In one study [30], a significant circadian rhythm of ICR was found, with the highest excretion in the late afternoon $-25.8 \%$ more than between 7 and 10 a.m. - indicating a dependence of ICR on lunch. Rasmussen et al. [1] suggested avoiding non-fasting samples in the morn- ing since UI excretion concentrations seemed to be lowest then. In contrast, Busnardo et al. [9] reported only small variations in UI excretion concentrations in nonfasting subjects. Taking the time of sampling into account, the main results of our analyses did not substantially change.

Assessing UI excretion from 24-hour urine is the most reliable method [31, 32]. However, collection of 24-hour urine is difficult and uncomfortable, hence spot urine samples normalized to creatinine concentrations are often used to determine an individual's UI excretion. It has previously been shown that iodine measurements in 24hour urine and spot urine samples are comparable [33, $34]$ and yield similar results if age- and sex-specific urinary creatinine excretion is accounted for $[19,35]$.

One limitation of our study is the characterization of nutritional habits. A food frequency questionnaire is not the gold standard for determining food intake in this context $[24,36,37]$. It only provides a rough estimate of dietary habits, which correspondingly did not allow us to examine whether, for example, a sustained higher iodized salt intake in a subgroup of males might have contributed to the stronger association. Even though more valid dietary records would have been available in the present study, we were not able to precisely calculate the iodine intake in the individual person. The German iodine fortification program is based on a voluntary principle, whereby food producers such as canteens, restaurants, private bakeries or butchers are not obliged to extra declare the usage of iodized salt [38]. Thus, in comparison to countries that introduced obligatory iodine programs with strict directives on what types of food have to be fortified with clearly defined concentrations, the iodine content of German food might vary, and the consumers are usually not aware of the exact iodine content.

Since we only collected information on food intake at baseline, it also remains unclear whether participants had changed their nutritional habits between baseline and follow-up. The weak association between low UI concentrations at baseline and follow-up, however, argues against the idea that unstable nutritional habits over time substantially confounded the association between high UI concentrations at baseline and follow-up. Further limitations might have arisen from underreporting medication. While in SHIP information on drugs is carefully collected, we cannot fully exclude recall bias regarding iodine medication, which might be particularly present for over-the-counter drugs [39] or repeated administration of iodine-containing contrast agents. 
In conclusion, we detected only a weak correlation with respect to low ICR. Studies assessing the iodine status in a population should take into account that an individual with a low UI excretion in one measurement is not necessarily permanently iodine deficient. On the other hand, current high ICR is predicted by high ICR 5 years ago. The mechanisms underlying this relation are currently not clear. Genetic and non-hereditary determinants of metabolic and renal iodine handling might represent a hypothetical explanation, but also residual confounding cannot unequivocally be ruled out.

\section{Acknowledgements}

The work is part of the Community Medicine Research net of the University of Greifswald, Germany, which is funded by the Federal Ministry of Education and Research (grant No. ZZ9603), the Ministry of Cultural Affairs as well as the Social Ministry of the Federal State of Mecklenburg-West Pomerania. The Community Medicine Research net encompasses several research projects which are sharing data of the population-based Study of Health in Pomerania (SHIP; http://www.medizin.uni-greifswald.de/ $\mathrm{icm} /$ ). Analyses were further supported by a grant of the German Research Foundation (DFG Vo 955/5-1).

\section{References}

1 Rasmussen LB, Ovesen L, Christiansen E: Day-to-day and within-day variation in urinary iodine excretion. Eur J Clin Nutr 1999; 53:401-407.

2 Als C, Helbling A, Peter K, Haldimann M, Zimmerli B, Gerber H: Urinary iodine concentration follows a circadian rhythm: a study with 3,023 spot urine samples in adults and children. J Clin Endocrinol Metab 2000; 85:1367-1369.

3 Saxholt E: Levnedsmiddeltabeller, ed 4. Copenhagen, Levnedsmiddelstyrelsen, 1996.

4 Als C, Haldimann M, Burgi E, Donati F, Gerber H, Zimmerli B: Swiss pilot study of individual seasonal fluctuations of urinary iodine concentration over two years: Is agedependency linked to the major source of dietary iodine? Eur J Clin Nutr 2003;57:636646.

5 Girelli ME, Coin P, Mian C, et al: Milk represents an important source of iodine in schoolchildren of the Veneto region, Italy. J Endocrinol Invest 2004;27:709-713.

6 Andersen S, Karmisholt J, Pedersen KM, Laurberg P: Reliability of studies of iodine intake and recommendations for number of samples in groups and in individuals. $\mathrm{Br} \mathrm{J}$ Nutr 2008;99:813-818.

7 Andersen S, Pedersen KM, Pedersen IB, Laurberg P: Variations in urinary iodine excretion and thyroid function: a 1-year study in healthy men. Eur J Endocrinol 2001;144: 461-465.

8 Bourdoux P: Evaluation of the iodine intake: problems of the iodine/creatinine ratio comparison with iodine excretion and daily fluctuations of iodine concentration. Exp Clin Endocrinol Diabetes 1998;106(suppl 3):S17-S20.

9 Busnardo B, Nacamulli D, Zambonin L, Mian C, Piccolo M, Girelli ME: Restricted intraindividual urinary iodine concentration variability in nonfasting subjects. Eur J Clin Nutr 2006;60:421-425.
10 World Health Organization: Assessment of Iodine Deficiency Disorders and Monitoring Their Elimination. A Guide for Programme Managers. Geneva, WHO, 2001.

11 John U, Greiner B, Hensel E, et al: Study of Health In Pomerania (SHIP): a health examination survey in an east German region: objectives and design. Soz Praventivmed 2001; 46:186-194.

12 Meng W, Scriba P: Jodversorgung in Deutschland, Probleme und erforderliche Maßnahmen: Update 2002 (Iodine Supply in Germany, Problems and Required Measures: Update 2002). Dtsch Ärztebl 2002;99: A2560-A2564.

13 Winkler G, Doring A: Validation of a short qualitative food frequency list used in several German large scale surveys. Z Ernahrungswiss 1998;37:234-241.

14 Brunn J, Block U, Ruf G, Bos I, Kunze WP, Scriba PC: Volumetric analysis of thyroid lobes by real-time ultrasound. Dtsch Med Wochenschr 1981;106:1338-1340.

15 Gutekunst R, Becker W, Hehrmann H, Olbricht W, Pfannenstiel P: Ultrasonic diagnosis of the thyroid gland (in German). Dtsch Med Wochenschr 1988;113:1109-1112.

16 Lorenz-Wawschinek O, Tiran B, Eber O, Langsteger W: Photometric determination of iodine in urine. Exp Clin Endocrinol 1994; 102:57-58.

17 Taussky HH: A microcolorimetric determination of creatine in urine by the Jaffe reaction. J Biol Chem 1954;208:853-861.

18 Kesteloot H, Joossens JV: On the determinants of the creatinine clearance: a population study. J Hum Hypertens 1996;10:245249.

19 Knudsen N, Christiansen E, Brandt-Christensen M, Nygaard B, Perrild H: Age- and sex-adjusted iodine/creatinine ratio. A new standard in epidemiological surveys? Evaluation of three different estimates of iodine excretion based on casual urine samples and comparison to $24 \mathrm{~h}$ values. Eur J Clin Nutr 2000;54:361-363.
20 Zou G: A modified Poisson regression approach to prospective studies with binary data. Am J Epidemiol 2004;159:702-706.

21 von Elm E, Altman D, Egger M, Pocock S, Gøtzsche P, Vandenbroucke J: STROBE Initiative. The Strengthening the Reporting of Observational Studies in Epidemiology (STROBE) statement: guidelines for reporting observational studies. Ann Intern Med 2007;147:573-577.

22 Zimmermann MB. Iodine deficiency. Endocr Rev 2009;30:376-408.

23 Preedy VR, Burrow GN, Watson RR: Comprehensive Handbook of Iodine: Nutritional, Biochemical, Pathological and Therapeutic Aspects. New York, Academic Press, 2009.

24 Wahl R, Pilz-Mittenburg KW, Heer W, Kallee E: Iodine content in diet and excretion of iodine in urine (in German). Z Ernahrungswiss 1995;34:269-276.

25 Koutras DA, Marketos SG, Rigopoulos GA, Malamos B: Iodine metabolism in chronic renal insufficiency. Nephron 1972;9:55-65.

26 De Braekeleer M, Mayer G, Chaventre A: Genetic factors in iodine deficiency disorders: a general review. Coll Antropol 1998;22:9-15.

27 Spitzweg C, Dutton CM, Castro MR, et al: Expression of the sodium iodide symporter in human kidney. Kidney Int 2001;59:10131023.

28 Thomson CD, Smith TE, Butler KA, Packer MA: An evaluation of urinary measures of iodine and selenium status. J Trace Elem Med Biol 1996;10:214-222.

29 Sackett-Lundeen L, Nicolau GY, Lakatua DJ, et al: Circadian and seasonal variation in iodine excretion in children in an endemic goiter area. Prog Clin Biol Res 1990;341A:689698.

30 Manz F, Bohmer T, Gartner R, Grossklaus R, Klett M, Schneider R: Quantification of iodine supply: representative data on intake and urinary excretion of iodine from the German population in 1996. Ann Nutr Metab 2002;46:128-138. 
31 Hetzel BS, Dunn JT: The iodine deficiency disorders: their nature and prevention. Annu Rev Nutr 1989;9:21-38.

32 Remer T, Fonteyn N, Alexy U, Berkemeyer S: Longitudinal examination of 24-hour urinary iodine excretion in schoolchildren as a sensitive, hydration status-independent research tool for studying iodine status. Am J Clin Nutr 2006;83:639-646.

33 Thomson CD, Colls AJ, Conaglen JV, Macormack M, Stiles M, Mann J: Iodine status of New Zealand residents as assessed by urinary iodide excretion and thyroid hormones. Br J Nutr 1997;78:901-912.
34 Vought RL, London WT, Lutwak L, Dublin TD: Reliability of estimates of serum inorganic iodine and daily fecal and urinary iodine excretion from single casual specimens. J Clin Endocrinol Metab 1963;23:1218-1228.

35 Remer T, Manz F: The inadequacy of the urinary iodine-creatinine ratio for the assessment of iodine status during infancy, childhood and adolescence. J Trace Elem Electrolytes Health Dis 1994;8:217-219.

36 Gartner R, Manz F, Grossklaus R: Representative data of iodine intake and urinary excretion in Germany. Exp Clin Endocrinol Diabetes 2001;109:2-7.
37 Rasmussen LB, Ovesen L, Bulow I, et al: Evaluation of a semi-quantitative food frequency questionnaire to estimate iodine intake. Eur J Clin Nutr 2001;55:287-292.

38 Brauer VF, Brauer WH, Fuhrer D, Paschke R: Iodine nutrition, nodular thyroid disease, and urinary iodine excretion in a German university study population. Thyroid 2005; 15:364-370.

39 Beitz R, Doren M, Knopf H, Melchert HU: Self-medication with over-the-counter (OTC) preparations in Germany (in Germany). Bundesgesundheitsblatt Gesundheitsforschung Gesundheitsschutz 2004;47: 1043-1050. 